\title{
Business Ethics: An Islamic Perspective
}

\author{
K. M. Anwarul Islam ${ }^{1}$ \\ Md. Rezaul Karim Miajee ${ }^{1}$ \\ ${ }^{1}$ Department of Business Administration, The Millennium University, Dhaka, Bangladesh \\ Correspondence: Department of Business Administration, the Millennium University, Dhaka, Bangladesh
}

Received: November 14, $2017 \quad$ Accepted: November 20, $2017 \quad$ Online Published: December 10, 2017

\begin{abstract}
The point of this paper was "Morals-The Islamic Perspective" is to pre-sent the moral strategy for directors from an Islamic viewpoint.In the advanced world, the western/contemporary school of thought presents different ideas to cover business morals that don't really apply to qualities, ethics, and morals as communicated through the Islamic focal point.
\end{abstract}

Keywords: Islamic Principles, Business Ethics, Islamic Perspective.

\section{Introduction}

This Paper investigates the need of IBE; it points of interest why Islam tends to business morals. We at that point consider the law of reasonability and business in Islam, trailed by consultation on the Islamic moral framework that shapes the center of morals related with any stroll throughout everyday life.

The reasons are built utilizing explicit refrains from the Holy Quran that are connected to business and business morals specifically. The content underneath will use direction from the Holy Quran-divine original copy disclosed to the sacred prophet Muhammad (pbuh) — the expressions of the blessed prophet, known as hadith? As people participate in work, experiencing moral issues isn't rare. As accentuated in the basic comments of the course book, I have uti-lized the examination approach all through the content to help perusers under-stand the distinction between the western/contemporary school and the Islamic school of thought unambiguously. The moral framework from an Islamic point of view is distinctive in its exceptionally establishment from the western contemporary moral framework that does not consider the job of religiosity in characterizing morals.

\section{2, Data Analysis}

On account of business morals, the option moral frameworks, for example, utilitarian, social relativism, universalism, rights, and equity approach are constantly open to changes and modification. What's more, choices induced for a similar circumstance fluctuate limitlessly dependent on various moral frameworks. Then again, the Islamic moral framework is preset, decided, and very much characterized dependent on inductions from the sources characterized. The key distinction between Islamic moral point of view and the other moral framework is explained in Table-1. 
Table-1Comparison of Islamic ethical perspective and the alternate ethical system

\begin{tabular}{|c|c|c|}
\hline Ethical system & Meaning & $\begin{array}{l}\text { Islamic ethical } \\
\text { perspective }\end{array}$ \\
\hline Utilitarian system & $\begin{array}{l}\text { Calculates costs versus bene- } \\
\text { fits, that is, an act is deemed } \\
\text { morally correct and right if } \\
\text { the net benefits over costs } \\
\text { (greatest good) are greatest } \\
\text { for the majority (greatest } \\
\text { number). }\end{array}$ & $\begin{array}{l}\text { Islam does not serve the in- } \\
\text { terest or benefit of a specific } \\
\text { subject involved; instead any } \\
\text { dilemma is resolved using } \\
\text { the set of rules from the Holy } \\
\text { Quran, prophet's sayings, } \\
\text { and Sunnah, and is not } \\
\text { affected by the quantity of } \\
\text { beneficiaries. }\end{array}$ \\
\hline $\begin{array}{l}\text { Individualism view of } \\
\text { ethics }\end{array}$ & $\begin{array}{l}\text { Fundamentally serves one's } \\
\text { long-term self-interests. }\end{array}$ & $\begin{array}{l}\text { If one's self-interests are } \\
\text { aligned with Allah's com- } \\
\text { mands, then this is the way } \\
\text { a decision should be made; } \\
\text { however, if it JUST serves } \\
\text { one's own ego, this is } \\
\text { certainly unacceptable. }\end{array}$ \\
\hline $\begin{array}{l}\text { Moral-rights view of } \\
\text { ethics }\end{array}$ & $\begin{array}{l}\text { Protects the fundamental } \\
\text { rights of all people, for exam- } \\
\text { ple, employees' rights, free } \\
\text { speech, health and safety, } \\
\text { and so forth. }\end{array}$ & $\begin{array}{l}\text { The moral-rights view } \\
\text { covers just a minor section of } \\
\text { Islamic business ethics (IBE) } \\
\text { Hence it can be treated as } \\
\text { a component of IBE only so } \\
\text { long as rights of the employ- } \\
\text { ees are those approved by the } \\
\text { Islamic laws (the superset as } \\
\text { defined in Figure } 2.1 \text { ). }\end{array}$ \\
\hline Justice view of ethics & $\begin{array}{l}\text { Fair and impartial treatment } \\
\text { of people according to legal } \\
\text { rules and standards. }\end{array}$ & $\begin{array}{l}\text { Certainly fair and impartial } \\
\text { treatment is a universal set } \\
\text { of "right" behavior; however, } \\
\text { the main concern is the set of } \\
\text { legal rules. The benchmark } \\
\text { set of standards needs to be } \\
\text { the Islamic standards that } \\
\text { should be the superset as } \\
\text { referred to in the discussions } \\
\text { below. }\end{array}$ \\
\hline
\end{tabular}

It is obvious from the depiction given in Table-1 that when seen from the Islamic focal point, none of the moral viewpoints are finished. Indeed, the utilitarian methodology peruses mistaken.

The imperfections in each of these likely could be talked about as a major aspect of classroom exercise or roundtable dialog in an office meeting while setting the set of principles. The thoughts can concentrate on the lacks and the cover of the western/contemporary moral methodologies when contrasted and the Islamic moral point of view.

Having contacted upon the major moral perspectives found in the western/contemporary school of figured, I will currently illuminate perusers on what are moral models in Islam and how these are connected to the supplanting and prevailing law of reasonability.

The Holy Quran in the verse (ayah) quoted below, emphasizes the order of trust. 
The above refrain clarifies that in any matter of concern the initial step is consultation with mates and fellowmen. Those from whom exhortation is looked for consider different elements related with the issue with the end goal to favor a goals, following which, a choice is sought after. After this basic leadership process, the Holy Quran prompts a devotee should put his total rust in Allah (SWT). In Islam, discussion is set as an approach to practice one's astuteness; as the idiom goes, two heads are superior to one. It is described from Imam Ali that:

One who only follows his own opinion will perish, but one who consults people shares with them in their intellect

\section{Conclusion}

In business and business managing situations, more than regularly one starts depending on the individuals who are put in higher positions that are predominant assignments, for example, one's supervisor, revealing expert, line chief, head $\mathrm{m}$ of the division, etc. This summons the manner of thinking that other factors are sufficiently powerful to be a reason for occurrences. Tawakkal is an idea that urges adherents to comprehend that the best arrangement lies with the preeminent expert as explained in the ayah beneath.

And Allâh is the Best of providers(Quran 62: 11)

\section{References}

Weir,D.(2008). Islamic perspectives on management and organization: International Journal of Islamic and Middle Eastern Finance and Management 1(1), 84-87.

Quran

\section{Copyrights}

Copyright for this article is retained by the author(s), with first publication rights granted to the journal.

This is an open-access article distributed under the terms and conditions of the Creative Commons Attribution license (http://creativecommons.org/licenses/by/4.0/). 